A-C [ollett, R.] 1898 


\section{HARVARD UNIVERSITY.}

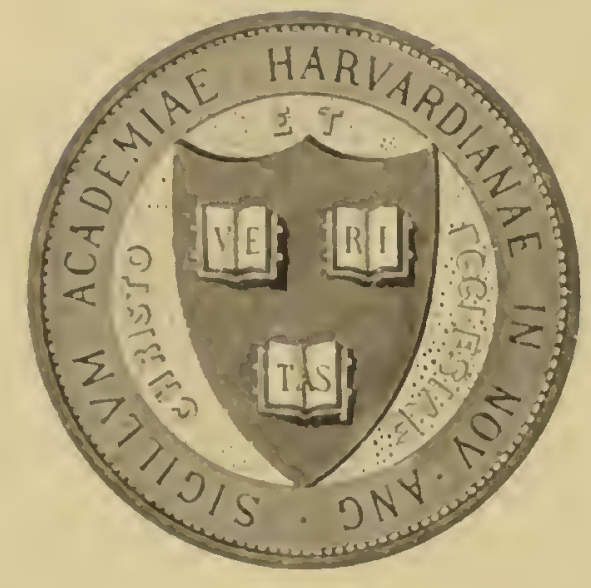

LIBRARY

(1) TIIF

MUSEUM OF COMPARATIVE ZOÖLOGY $-4.769$

BEQUEST OF

WH.I.I.M BREIISTISR

ure. 30,1420 


$$
54.769 .
$$

On a Second Collection of Birds from Thongod:

New Hebrides

by

R. Collett

(Christiania Videnskabs-Selskabs Forhandlinger 1898. No. 6)

\section{Christiania}

Sold on Commission by Jacob Dybwad

A. W. Brøgger, Printer 


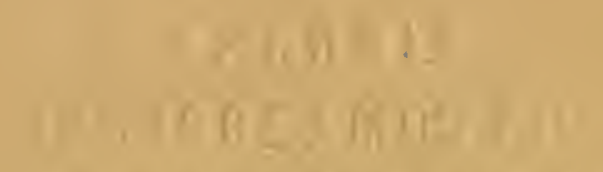

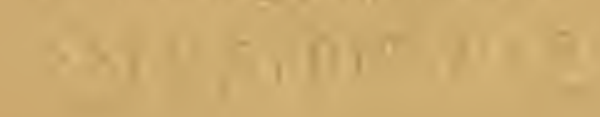




\section{On a Second Collection of Birds from Tongoa}

\section{New Hebrides}

by

R. Collett

(Christiania Videnskabs-Selskabs Forhandlinger 1898. No. (6)

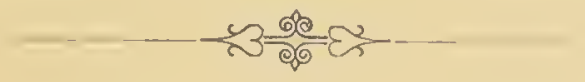

Christiania

Sold on Commission by Jacob Dybwad

A. W. Brøgger, Printer 



\title{
On a Second Collection of Birds from Tongoa, New Hebrides.
}

\author{
By
}

\section{R. Collett.}

(Read the 11th November 1898.)

In 1890, the Zoological Museum at Christiania received a small collection of birds from Tongoa, New Hebrides, which had been obtained by the Revd. Oscar Michelsen, who, for many years, was a missionary in those islands.

The collection, which comprised 20 species, has been described in Forh. Vid. Selsk. Skr. 1892 (No. 13). Of those, one (a Rhipidura) is possibly, a hitherto undescribed species, but this could not be accurately determined as the specimen was not complete. Another species, Rhipidura bulgeri, Lay. 1877, had previously not been known to inhabit the New Hebrides.

In 1897, a further collection was received from the Revd. O. Michelsen, like the former one, made in Tongoa. This was formed of but 7 species (besides a number of eggs), and included Puffinus obscurus, which has possibly not been previously recognised as belonging to the New Hebrides, but which resorts to those islands to breed. 


\section{Petroeca similis, Gray 1859.}

Petrocen similis. Gray, Cat. B. Trop. Isl. Pac. Ocean. p. 15 (1559).

Petroecu similis. Sharpe, Cat. B. Brit. Mus. Yol. IV (Fam. Mruscicupidae), p. 169 (18.9): Wiglesworth, Av. Polyn. p. 24 (1891).

\section{Specimen.}

Adult. Length of Wing, $60 \mathrm{~mm}$; Tail, $39 \mathrm{~mm}$.

It appears to be closely allied to $P$. pusilla, Peale 1848 (from Samoa and Fiji), and whether it is a distinct species is doubtful. The specimen is very dark in colour: the entire head and neck being almost black (but with a distinct sooty hue). The rump has traces of a white cross-band, as in $P$. pusilla.

Native name: Mann-miala (mann is bird, miala red). It feeds on flies and small moths. According to the matives it builds its nest on the branches of moss, bound together with cobweb, and lays two eggs.

\section{Erythmia regia, (Scl.) 1881.}

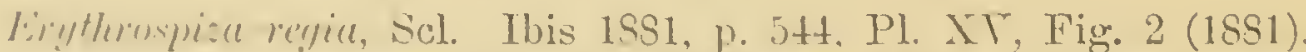

limllerume reyiue. Sharpe, Cat. B. Brit. Mus. Tol. XIII (Fam. Mloccidec), 1. 39.) 1890); Wiglesworth. Av. Polyn. 1) +2 (1891).

2 Specimens, (and 3 eggs).

A. Length of Wing, $63 \mathrm{~mm}$.; Tail, $35 \mathrm{~mm}$.

B. - - " $\quad 62$ " $\quad 32$,

To the description of Dr. Sclater may be added that, the secondaries on outer web, and the tertials on both webs are largely bordered with blue.

Native name: Ta-mahalida or Ta-puti. Ta means to peck, Ta-mahalida indicating the peculiar manner in which it pecks at the small figs which compose its food. Ta-puti signifies also, that it pulls up grass by the root. This is used in the construction of its large nest which has a litttle round hole in the side.

The nest contains 3 to 4 eggs. A clutch of eggs, said to belong to this species, was comprised in the collection; the eggs were white without gloss. (Length, $19 \mathrm{~mm}$., breadth, $15 \mathrm{~mm}$.). 


\section{Ptilopus greyi, G. R. Gray 1859.}

Ptitonopus greyii, G. R. Gray, List Birds Brit. Mus. Columbae p. 4 (1856; descr. nulla); Cat. Birds Trop. Isl. Pacif. Oc. p. 38 (1859).

Ptilopus greyi, Wiglesw., Av. Polyn. p. 51 (1891); Salvadori, Cat. B. Brit. Mus. Vol. XXI (Fam. 'T'reronidue), p. 85 (1893).

\section{Specimens.}

A. Adult; length of Wing, $123 \mathrm{~mm}$.; 'Tail, $60 \mathrm{~mm}$.

The yellowish band, bordering the rose top of the head is very feebly indicated (as in the specimens sent from the same locality in 1890).

$B$. Young, (probably belonging to $P$. greyi). Green, with no rose spot on head. Upper parts with narrow, lower parts with broad yellow edgings. Wing coverts and secondaries also with yellow edgings which are broader on the tertials. Primaries narrowly edged with whitish yellow. Under tail coverts yellow.

Native name: Suda (or Synda), or Dagi-ta-moru. In respect to the latter name it may be mentioned that Dagi (pronounced Ndangi) means to weep or mourn over the dead: moru means a hole. It has acquired the name because it, according to the account of the natives, „comes to the house of a sick person, and sings its dirge over the sick person's hole or grave".

\section{Megapodius layardi, Tristr. 1879.}

Megapodius layardi, Tristram, Ibis 1879, p. 194 (1879).

Megapodius layardi, Wiglesw. Av. Polyn. p. 58 (1891); Ogilvie-Grant, Cat. B. Brit. Mus. Tol. XXII (Fam. Megaporliidae), p. 459 (1893).

\section{Specimen, and 3 eggs.}

Adult; length of Wing, $245 \mathrm{~mm}$.; Tail, $90 \mathrm{~mm}$.

The eggs are of the following measurements:

a. Length, $86 \mathrm{~mm}$. Breadth, $47 \mathrm{~mm}$.

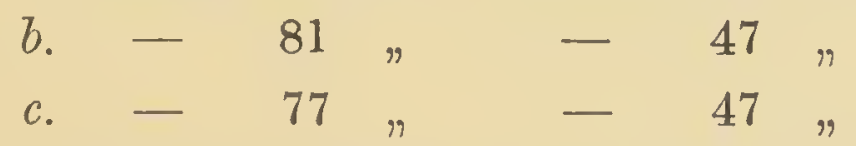

The last egg seems to belong to another set (or hen). It is shorter, and the colour is a paler green than in the others. 
Native name: Malau. It buries its eggs in crumbling, rotten, stumps of trees, or in places, where the earth is subterraneously warmed by volcanic heat (a few such spots exist in Tongoa, where, probably, in the course of time, active volcanoes will appear).

It often happens that many hens will bury their eggs at the same spot. and the natives can thus obtain several scores at a time.

It lives on white ants, and various kind of insects and their larvæ. which it finds in the decaying roots of trees.

Mypotaemidia phitimpinensis, (Lin.) 1766.

Rullus philipunuix. Lin. Syst. Nat. ed. XII. p. 203 (1766).

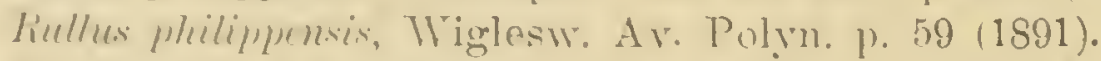

Mypolumilia philippinemis, Sharpe, Cat. B. Brit. Mus. Yol. XXIII (Fam. licullidue), p. 39 (1894).

\section{Specimen, and 7 eggs.}

The single specimen was a young in down, probably belonging to this species. Colour of the down black; length of culmen (from the down-covered portion of the forehead), $13 \mathrm{~mm}$; the middle toe, with claw, $28 \mathrm{~mm}$.

Bill, blackish brown; the tip of the lower bill, light horn colour.

The eggs are almost equal in size and colour of those of Rallus aquaticus, Their average dimensions were, length, $37 \mathrm{~mm}$., breadth. $29 \mathrm{~mm}$. (the shortest example was $35 \mathrm{~mm}$., in length; the longest. $3 \& \mathrm{~mm}$.).

Native name: Pilake.

Charadrins dominicus, Mïll. 1776.

(Wamalvius dominirus, P. S. Müller. Nat. Srst. (nach Lin., ed. XII). Suppl. 1. $116(17 \% 6$ !

(tumalrius fulus. Wiglesw. Ar. Polyu. p. 63 (1891). Charadrius dominicus. Sharpe, Cat. B. Brit. Mus. Tol. XXIY (Fam. Charadriidae), p. $195(1996$ ! 


\section{Specimen.}

Adult, in worn (summer) plumage; length of Wing, $165 \mathrm{~mm}$.; 'Tail, $64 \mathrm{~mm}$.

Native name: Siviu. It feeds upon some small crustaceans which leap about, amongst the stones on the beach, after the waves have rolled over them.

\section{Puffinus obscurus, (Gmel.) 1788.}

Procellariu obscura, Gmol., Syst. Nat. Ed. XIII, 'Tom. 1, p. 559 (1788).

Puffimus obscurts, Wiglosiv., Av. Polyn. p. 79 (1891); Salvin, Cat. B. Brit. Mus. Vol. XXV (Fam. L'uffinidue), p. 382 (1896).

\section{Specimens.}

A. Adult male; length of Wing, $210 \mathrm{~mm}$.; Tail, $76 \mathrm{~mm}$.

The larger tail coverts entirely blackish brown, only one or two with faint traces of a white tip.

$B$. Young in down. Upper surface a light greyish brown, under surface whitish; feet and bill coloured as in the adult.

On the New Hebrides, $P$. obscurus has one of its resorts for breeding purposes. During the daytime it lives in holes which it digs in the ground far up in the woods, and seeks its food during the course of the night.

According to native accounts it sleeps, resting on one foot. They believe that, "prior to leaving its nest, it places a light coloured sponge at the entrance in order to find it again". It is presumed that some five or six individuals inhabit each burrow.

Native name: Ngon-go (or Ngo-ngo). 



1.

- $-1=$

-

$-$ 
$x$

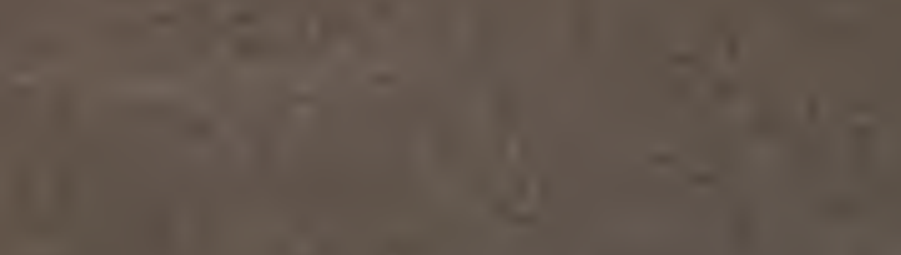

$-2$

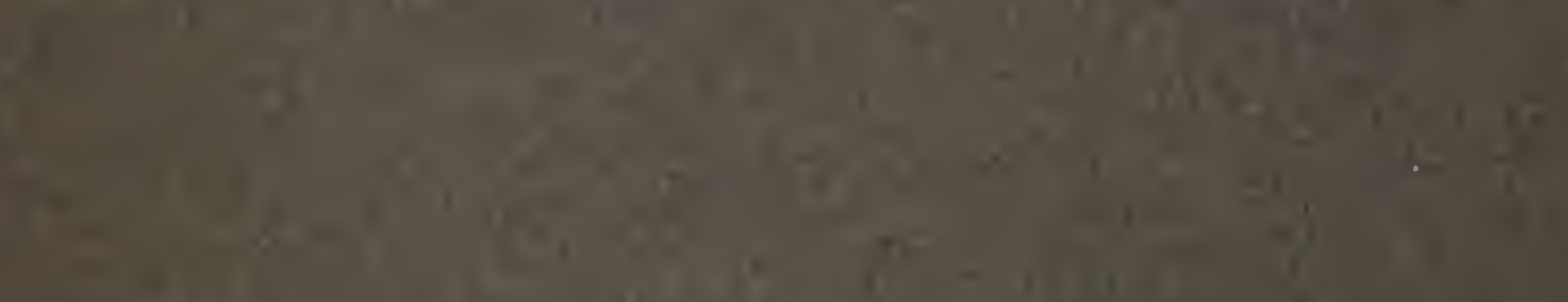

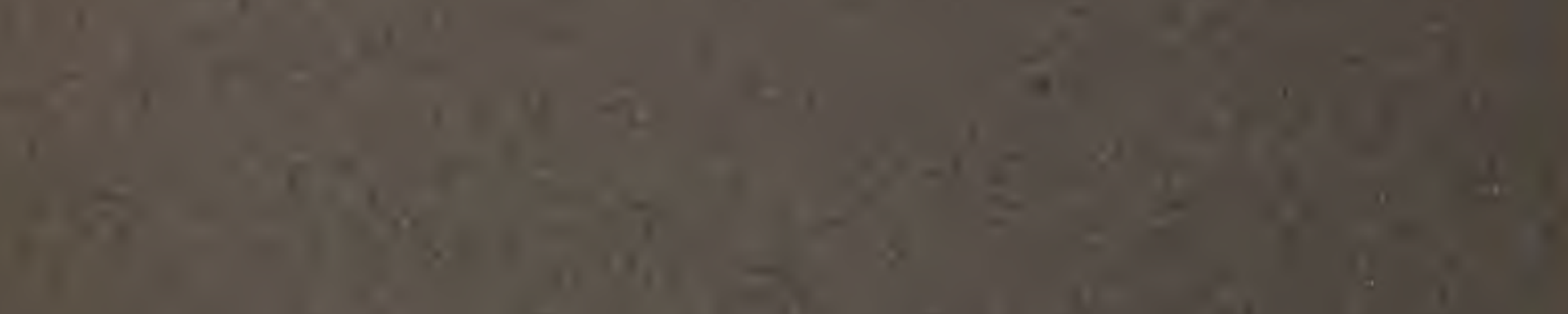

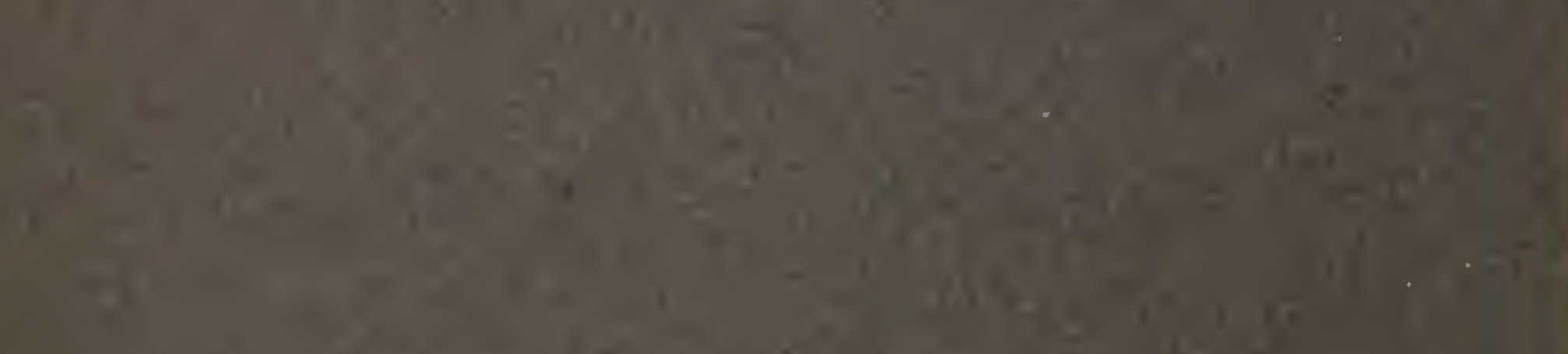

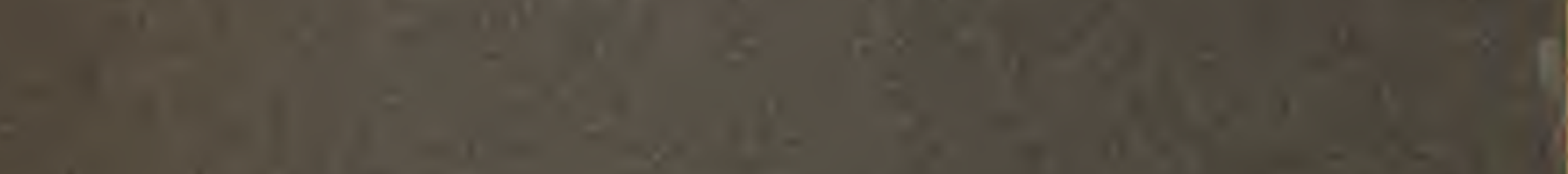

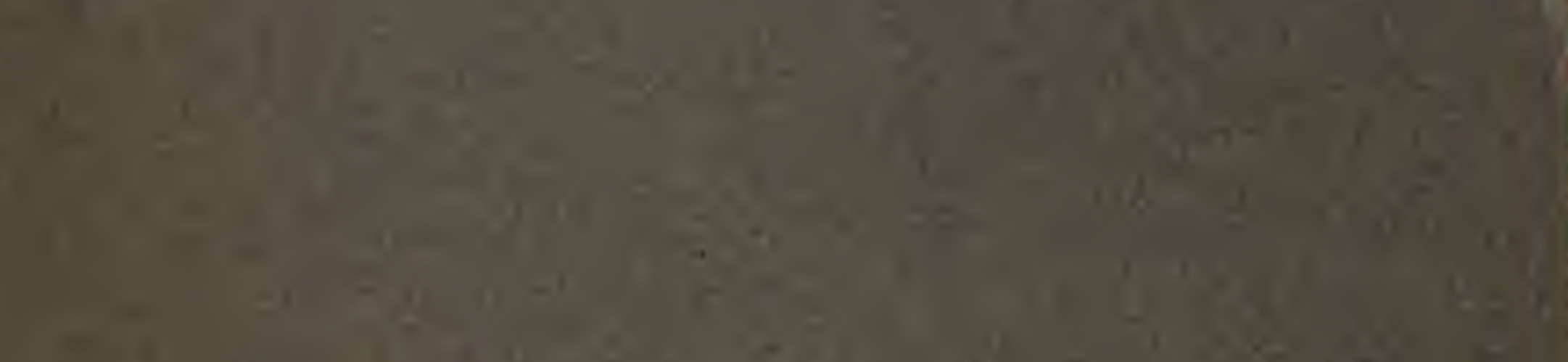

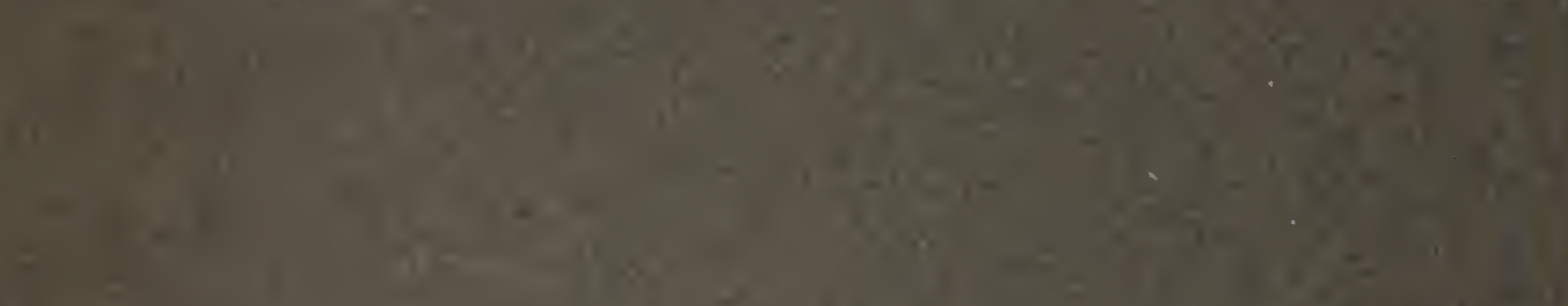

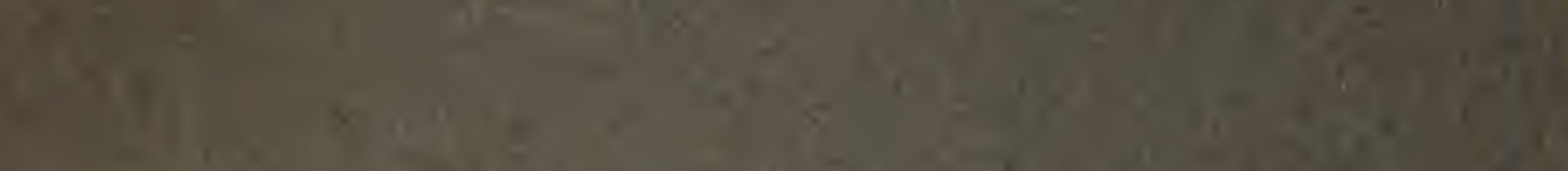

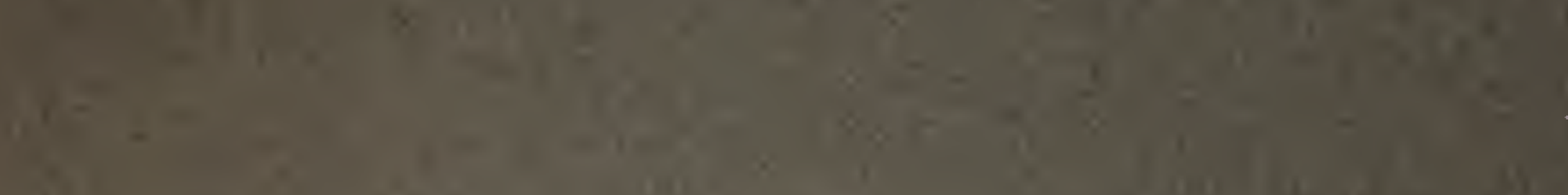
$2=1$ i $\frac{x+2}{6-21}$

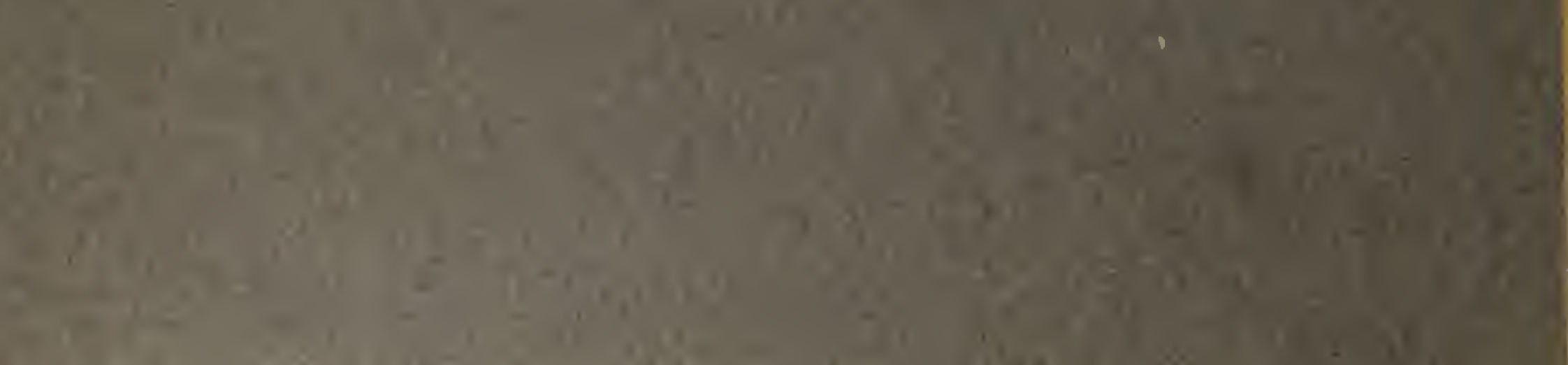

